\title{
DIE SUID-AFRIKAANSE MOTORFIETSKORPS
}

\section{ET S. J. FERREIRA}

\begin{abstract}
With the conclusion of the German South West Airican campaign, the Imperial Government requested the participation of the Union Defence Forces in the German East African campaign. As a result of experience acquired during the former campaign as well as knowledge of the rugged East African terrain, the need for a highly mobile and independent unit was considered essential. This heralded the establishment of the South African Motor Cycle Corps.
\end{abstract}

During the East African campaign this Corps served with General Van Deventer's 2 Division as a support and reconnaissance unit. In 1917 the Corps was attached to the forces under General Northey, where it saw action both in infantry and reconnaissance capacities.

When peace negotiations got underway in 1918, the Germans had retreated to Abercorn, and the South African Motor Cycle Corps returned to the Union. On arrival the Corps was immediately disbanded, and, while having no battle honours conferred, nevertheless had done excellent work and had become the first unit in South African military history to be equipped with motor cycles.

\section{Stigting}

Met die stigting van die Unieverdedigingsmag in 1912 was dit onmoontlik om te besef dat SuidAfrika so gou in 'n grootskaalse oorlog betrokke sou raak. Nadat die Imperiale Regering oorlog teen Duitsland verklaar het, word Suid-Afrika outomaties by die Eerste Wêreldoorlog betrek.

Die Unieverdedigingsmag het onmiddellik ' $n$ veldtog teen die Duitse magte in Suidwes-Afrika geloods en in 1915 word die gebied onderwerp. Daarop versoek die Imperiale Regering the Unie regering om troepe na Duits Oos-Afrika te stuur om die veldtog daar te steun.

Die Unieverdedigingsmag het intussen waardevolle lesse tydens die Duits Suidwes-Afrika veldtog geleer. Een daarvan was die behoefte aan die oprigting van 'n gemotoriseerde eenheid. Sodanige eenheid moes as 'n snel bewegende en onafhanklike gevegseenheid, teen die Duitse Magte kon optree. Daarby moes die nuwe Oos-Afrika gevegsterrein met sy swak paaie en tropiese plantegroei, die spoed van die gemotoriseerde eenheid so min as moontlik belemmer.

Die Direkteur Oorlogswerwing wat met die taak belas was, het in Januarie 1916 'n spesiale Komitee aangestel om 'n eenheid wat aan die vereistes voldoen, op te rig. Op 18 Januarie het die Komitee in Johannesburg byeengekom. ${ }^{1}$

Die Komitee se taak het die vasstelling van die korpssterkte, werwing van die nodige lede, die kies van ' $n$ bevelvoerder en die keuse van 'n opleidingsentrum behels. ${ }^{2}$

Die Suid-Afrikaanse Motorfietskorps, soos die korps hierna bekend sou staan, se sterkte is vasgestel op 406 lede wat soos volg onderverdeel is:

$\begin{array}{lrr}\text { Hoofkwartier } & - & 33 \text { lede } \\ 8 \text { Peletons } & - & 248 \text { lede } \\ \text { Rapportryers } & - & 57 \text { lede }^{3} \\ \text { Maandelikse } 10 \% \text { versterkings } & - & 34 \text { lede } \\ \text { Aanvanklike addisionele versterkings } & - & 34 \text { lede }\end{array}$

As bevelvoerder van die Suid-Afrikaanse Motorfietskorps is luitenant-kolonel James Mclntire Fairweather, DSO, aangestel. ${ }^{4}$ Kaptein Duncan McMillan, ' $n$ eertydse professor in ingenieurswese aan die Universiteit van Kaapstad, is as sy adjudant aangestel. Kaptein McMillan se aanstelling het berus op sy uitgebreide kennis aangaande die versorging, herstel en beheer van motorfietse.

Die motorfietsryers is in agt peletons verdeel onder

1. WWI, GSWA, Houer 108: Brief van die Hoof Stafoffisier aan die Direkteur Oorlogswerwing, gedateer 19 Januarie 1916

2. WWI GSWA Houer 108: Memorandum nr 140/1/10 van luitenant-kolonel C.R. Burgess, Stafoffisier Oorlogswerwing.

3. WWI, GSWA, Houer 108: Omsendbrief aan die Veldbetaalmeesters, 1917. Die Suid-Afrikaanse Rapportryerskorps het kort hierna afgestig om as 'n onafhanklike korps op te tree.

4. Tyldon G majoor The armed forces of South Africa, Johannesburg, 1954, p 171. Luitenant-kolonel Fairweather was voor sy aanstelling bevelvoerder van die Rand Light Infantry. 
aanvoering van luitenante R.H.O.D. Hoskyn, W. McHardy, J.O. Henrey, H.A.E. Hall, A.G. Ramsay, H.W. Kelly, H.E. Jackson, W.J. Houghton en M.N. Clark. ${ }^{5}$

Elke peleton het uit 31 lede bestaan. Hoewel elke peleton hulle eie werktuigkundiges gehad het, het die Hoofkwartier benewens seiners en drywers nog 'n verdere aantal werktuigkundiges ingesluit. Die rede vir die groot aantal werktuigkundiges was die noodwendige ruwe hantering waaraan motorfietse gedurende die Oos-Afrika veldtog onderworpe sou wees.

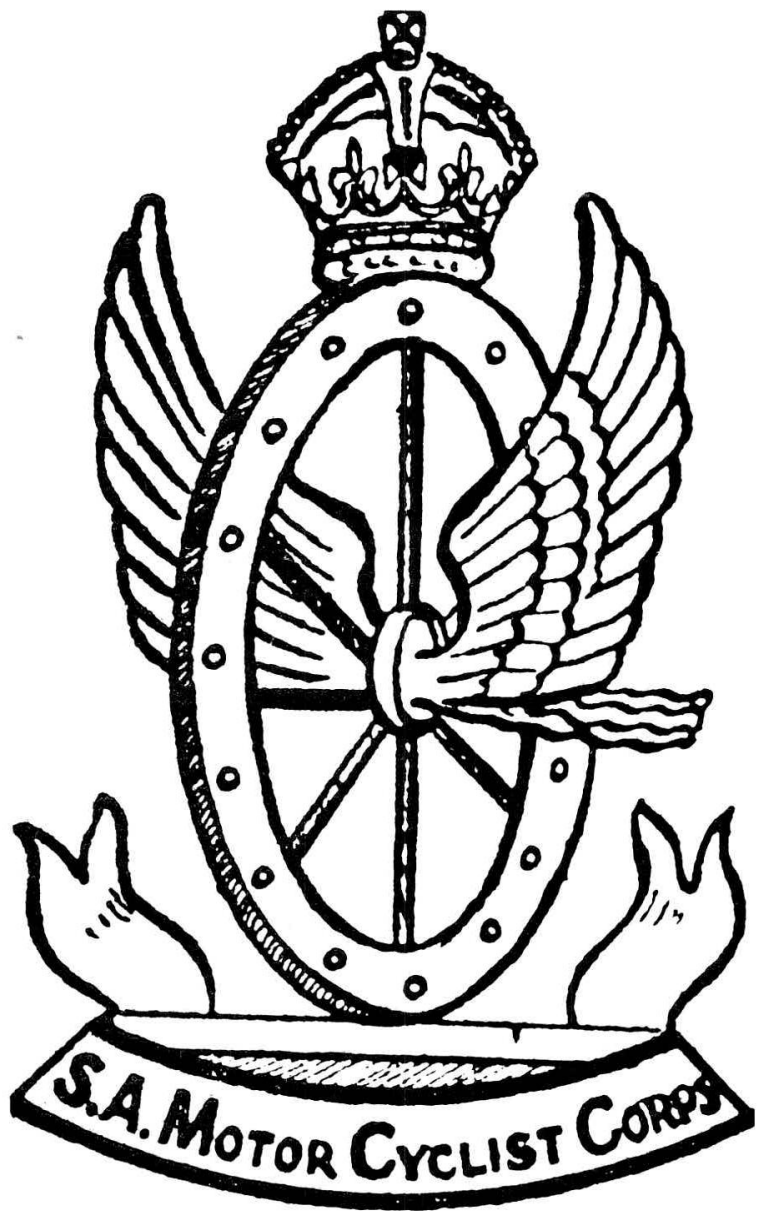

Embleem van die Suid-Afrikaanse Motorfietskorps. (Foto: SAW-Argief.)

Die werwing van geskikte lede was aanvanklik 'n moeisame taak. Om te kan kwalifiseer moes voornemende lede fisies en geestelik gesond wees. Daarby moes persone 'n grondige kennis en ryvernuf van motorfietse aan die dag lê. Die gedagte dat die Korps verteenwoordigend van die Unie as geheel moes wees, het daartoe aanleiding gegee dat werwing in al die groot sentra's gedoen is. Veral die spoorweë was goed verteenwoordig in die Korps.
Werwingsprobleme het egter daartoe aanleiding gegee dat opleidings- en mobilisasiedatums vanaf einde Januarie 1916 tot 12 Maart 1916 uitgestel moes word. ${ }^{6}$ Ten spyte daarvan was die Korps met die aanvang van die opleidingstydperk nog steeds tagtig lede onder oorlogsterkte. Hierop is besluit om van burgerlike instansies gebruik te maak om lede te werf.

In Johannesburg is die hulp van die Outomobiel Klub en in Durban die hulp van die Motorfietsklub ingeroep om motorfietsryers aan die moedig om by die SA Motorfietskorps aan te sluit. ${ }^{7}$

Hoewel daar steeds probleme met werwing ondervind was, is in Maart begin met opleiding te Potchefstroom. Omrede die Korps in April alreeds slaggereed moes wees, was die opleidingsprogram uiters beperk gewees. Gedurende die opleidingsperiode moes vyftig motorfietsryers uitgesoek word om onder bevel van kaptein Blackwell en luitenant Salmon na Oos-Afrika te vertrek om daar diens te doen as rapportryers.

\section{Persoonlike uitrusting en toerusting}

In Februarie 1916 het die Direkteur Meganiese Vervoer met 'n burgerlike instansie reëlings getref vir die aankoop van motorfietse. ${ }^{8} \mathrm{Na}$ onderhandelings oor watter tipe motorfietse die geskikste sou wees vir gebruik deur die Suid-Afrikaanse Motorfietskorps, is besluit om BSA motorfietse vanaf Engeland in te voer.

Daar was verskeie redes daarvoor verantwoordelik. Elke motorfiets kon benewens die drywer 'n verdere gewig van ongeveer 65 kilogram dra. Wanneer sonder die logistieke steun van motors beweeg moes word, was dit vir die drywer moontlik om sy persoonlike toerusting, rantsoene vir vier dae, 'n geweer, bajonet en honderd rontes patrone met hom saam te dra. Vir meer doeltreffende en sneller vuurkrag in geval van hinderlae, kon spesiale geweerhouers met Lewis masjiengewere of seinuitrusting aan die motorfietse monteer word. ${ }^{9}$

5. WWI, GSWA, Houer 109: Naamlys soos dit op 30 Maart 1916 verskyn het.

6. WWI, GSWA, Houer 102: Brief van luitenant-kolonel Fairweather aan die Stafoffisier, Union Imperial Service Unit, te Pretoria, gedateer 17 Februarie 1916.

WWI, GSWA, Houer 102: Brief van luitenant-kolonel Fairweather aan die Sekretaris van die Motorfietsklub in Durban, gedateer 17 Februarie 1916.

7. WWI, GSWA, Houer 108: Memorandum nr 140/1/10 van luitenant-kolonel C.R. Burgess, Stafoffisier Oorlogswerwing.

8. WWI, GSWA, Houer 102: Brief van Faimweather aan Shimwell Bros te Johannesburg gedateer 9 Februarie 1916.

9. WWI, GSWA, Houer 106: Memorandum van Fairweather aan brigadier-generaal E. Northey te Malingali, gedateer 9 Februarie 1917 


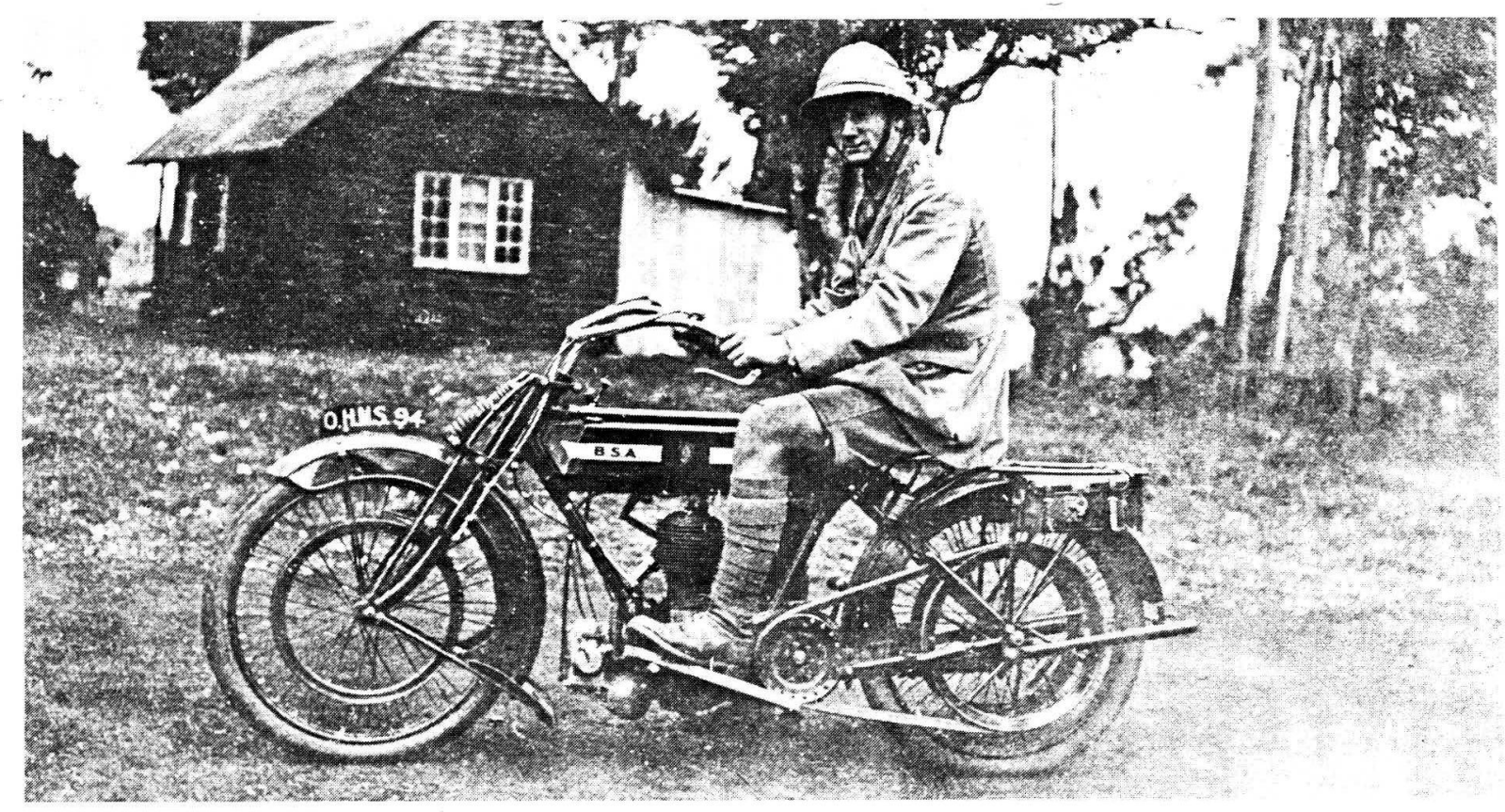

Voorbeeld van die motorfietse wat deur die Suid-Afrikaanse Motorfietskorps gebruik is. (Foto SAW-Argief.)

Die motorfietse het alreeds bewys dat ruwe terreine geen onmoontlike hindernis vir hulle was nie. Daarbenewens was onderdele maklik verkrygbaar en was dit moontlik om die motorfietse met die minimum tyd en inspanning diensbaar te hou.

Op 14 Februarie het die eerste besending van die 400 BSA motorfietse op die SS NORMAN in Durban aangekom. ' $n$ Week later het ' $n$ verdere veertig motorfietse met die UMVOLOS/ in Durban aangekom..$^{10}$ Van hier af is die motorfietse en onderhoudstoerusting dadelik na Potchefstroom vervoer.

Die uniforms van die Suid-Afrikaanse Motorfietskorps het bestaan uit ' $n$ staalhelm met ' $n$ geel diamantvormige kenteken omsirkel in rooi," 'n baadjie, hemp, Bedford koordrybroek, leerkamaste en 'British Warm'. In ongure weer is van helder geel reënbaadjies en broeke gebruik gemaak.

Die wapen van die Suid-Afrikaanse Motorfietskorps dui duidelik daarop dat die oorgrote meerderheid van die lede vroeër aan die spoorweë verbonde was. Die wapen wat aanvaar is, is ' $n$ aanpassing van die wapen wat deur die Railways and Harbours Brigade gebruik is. Hierdie brigade is spesiaal in die lewe geroep vir lede van die spoorweë. Dieselfde motief is ook te bespeur by die Central South African Railway Engineers Corps (1906 tot 1913) en die Railways and Harbours Rifles (vanaf 1 April 1940). Die wapen bestaan uit 'n gevleuelde wiel met die leuselint SAMCC, onderaan.

\section{Vertrek na Duits Oos-Afrika}

In April 1916 vertrek die Motorfietskorps of die South African Musical Comedy Corps, ${ }^{12}$ soos hulle spottenderwys bekendgestaan het, vanaf Potchefstroom na Durban. Daarvandaan vertrek die Korps met die SS Huntsgreen ${ }^{13}$ na Oos-Afrika

Die eentonige reis is deur kaptein McMillan terdeë benut. Vanuit die staanspoor het hy die lede se kennis verbreed met lesings oor die onderhoud en hantering van motorfietse. Die kort en in baie opsigte gebrekkige opleiding wat die lede in Potchefstroom ontvang het, het die stappe genoodsaak. Elke moontlike tydjie is gedurende die reis gewy aan verdere opleiding.

Met die aankoms van die Suid-Afrikaanse Motor fietskorps in Kilindini, breek daar 'n epidemie van waterpokkies aan boord van die SS Hüritsgreen uit. Gevolglik moes die Korps dadelik na Voi vertrek, waar hulle drie weke in afsondering deurgebring het. ${ }^{14}$

10. WWI GSWA Houer 102: Brief van Fairweather aan Shumwell Bros, te Johannesburg gedateer 9 Februarie 1916

11. WWI, GSWA, Houer 102: Brief van Fairweather aan die Stafoffisier, 'Imperial Service Units', in Pretoria. Die bron meld dat die aanvanklike kenteken van die SA Motorfietskorps geel was met die St Andrews kruis daarop. Die kenteken is egter nooit gebruik omrede die verwarring wat dit met lede van die St John's Red Cross kon veroorsaak

12. AG(3), Hover 204. Versiag deur sersant IR Williams opgestei in 1943

13. Die skip was voorheen 'n Duitse skip bekend as die Derfinger.

14. WWI, GSWA, Houer 106: Memorandum van Farrweather aan brigadier-generaal Northev te Malingalı, gedateer 9 Februarie 1917 
Scientia Militaria, South African Journal of Military Studies, Vol 8, Nr 3, 1978. http://scientiamilitaria.journals.ac.za

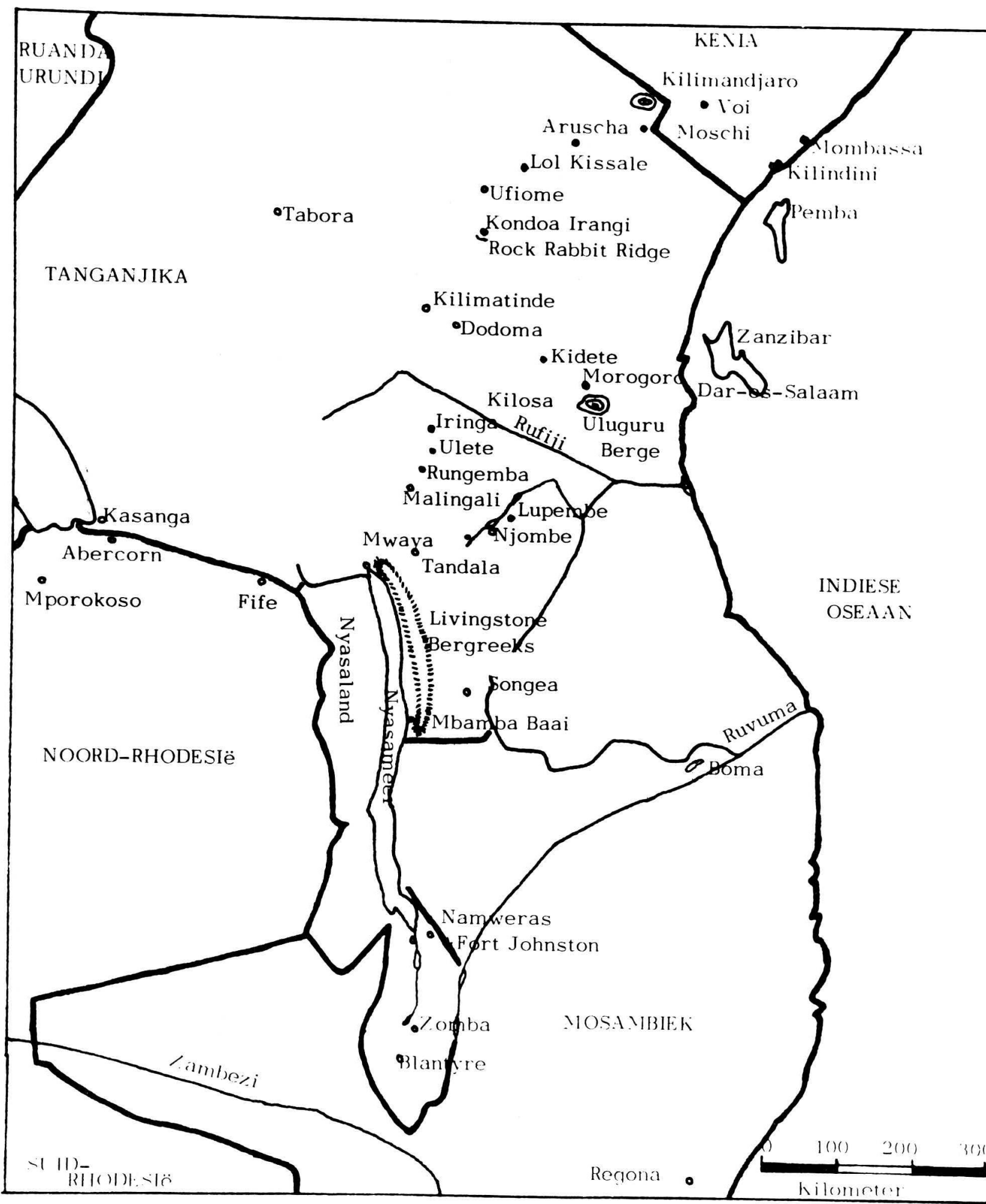

Duits Oos-Afrika Veldtog, 1916 - 1918.

14 
Dit was slegs die begin van hulle ontberinge. OosAfrika, met sy tropiese klimaat en plantegroei, het weldra sy tol begin eis aan epidemies en tropiese siektes. Dit was veral te wyte aan die feit dat gedurende die eerste tien maande van aktiewe diens op hierdie front, dit wil sê, tot en met Februarie 1917, diens deur die Motorfietskorps hoofsaaklik in koors areas verrig is. So erg was die koors epidemie dat gedurende krygsoperasies in Kondoa Irangi, bykans negentig persent van die lede koors onder lede gehad het. ${ }^{15}$

Koors was egter nie die enigste probleem nie. Die Korps se eerste opdrag het hulle van Voi na Moschi gevoer. Die laaste gedeelte van die tog, dit wil sê vanaf die Himo rivier, is in die donker onderneem en dit op onbekende en onbegaanbare paaie. $\mathrm{Na}$ die opmars het die lede verstom gestaan en kyk na die silhoeët van die berg Kilimandjaro teen die helder maanlig soos dit vanaf Moschi besigtig kon word.

Die lang reis na Kondoa Irangi moes egter voortgesit word. Vanaf Aruscha is hulle verder na Pienaars Heights waar hulle 'n groepie Afrikaanssprekende boere teëgekom het wat in die distrik woonagtig was. Van hier af is die laaste gedeelte van die reis deur Lol Kissale en Ufiome na Kondoa Irangi voortgesit. Op die reis moes verskeie riviere deurkruis word. Motorfietse moes dikwels met behulp van pale oor die riviere gedra word.

Van die sanderige en ruwe paaie kon daar nie afgewyk word nie, aangesien die gevaar bestaan het om in ' $n$ vangput wat deur swartes vir die vang van diere gemaak is, te beland.

\section{Aansluiting by generaal Sir J.L. van Deventer}

Nadat die Suid-Afrikaanse Motorfietskorps in Kondoa Irangi aangekom het, is hulle dadelik by 2 Divisie ingedeel en onder bevel van generaal Van Deventer geplaas. Die Korps se motorfietse is by ' $n$ hospitaal, sowat vier kilometer buite die stad gelaat. Stelling is op ' $n$ koppie met die naam van Rock Rabbit Ridge, sowat sewe kilometer buite Kondoa Irangi, ingeneem. Vanweë die klipperigheid en naam van die koppie, is die Motorfietskorps heel gepas na Jimmy Fairweather's rock rabbits herdoop deur die omliggende infanterie eenhede.

'n Peleton van die Suid-Afrikaanse Motorfietskorps is hiervandaan na Loskop, 'n nabygeleë koppie. Vanaf die stellings is patrollies uitgestuur om kontak te maak met die Duitse linies wat sowat elf kilometer verder, rondom Kondoa Irangi stelling ingeneem het.

Op een geleentheid is ' $n$ patrollie motorfietsryers, onder bevel van luitenant Jackson driehonderd kilometer ver na die Mahenge Vlaktes gestuur. Die doel was om die Sentrale Spoorweë hier te saboteer om sodoende die Duitsers van die nodige voorrade af te sny. Die patrollie misluk egter vanweë die streng veiligheidsmaatreëls wat deur die Duitse magte getref is.

2 Divisie was egter baie verswak. Met slegs sewehonderd weerbare mans moes die Duitse magte onder bevel van generaal Von Lettow Vorbeck gestuit word. Aanvalle en opmarse in aanhoudende reën sowel as malaria het die getalle aan Suid-Afrikaanse kant aansienlik uitgedun. ${ }^{16}$ Die aansluiting van die Suid-Afrikaanse motorfietskorps by 2 Divisie het geen merkwaardige verskil gemaak indien die getalsoorwig van Von Lettow Vorbeck se magte in aanmerking geneem word nie.

Op 9 Mei val die Duitsers die verswakte 2 Divisie in Kondoa Irangi aan. Die Suid-Afrikaners is met vier duim Howitzers en vlootkanonne ${ }^{17}$ bestook. $\checkmark a n$ Deventer se magte word dieselfde dag aansienlik versterk deur die aankoms van ' $n$ infanterie brigade onder aanvoering van generaal Berrangé. Beide flanke sowel as die 2 Divisie Hoofkwartier is aangeval, maar is elke keer afgeweer met groot verliese aan Duitse kant. Berrangé se brigade was hoofsaaklik verantwoordelik vir Duitse verliese.

Eers in Junie kom versterkings in die vorm van swaar artillerie in Kondoa Irangi aan om Van Deventer te steun.

Hoewel die Union Jack bokant 2 Divisie Hoofkwartier gewapper het, is nog dié, nog die aangrensende hospitaal deur die swaar Duitse artillerie getref. Eers nadat die Rooi Kruis hospitaal sowat ' $n$ kilometer terug verskuif is, het 'n goedgemikte bom in die hoofsaal ontplof. Geen beserings behalwe ' $n$ openlike en onophoudelike gemor van die Duitse pasiënte is ondervind nie. Die

15. WWI, GSWA, Houer 106: Memorandum van Fairweather aan Northey te Malingali, gedateer 9 Februarie 1917.

16. Official History, The Union of South Africa and the Great War 1914 - 1918, Pretoria, 1924, p 71

17. Official History, op. cit., p 73.

Collyer, J.J., Brigade-generaal, Die Suid-Afrikaners met generaal Smuts in Duits Oos-Afrika, 1916, (Pretoria, 1939) p 33.

Die vlootkanonne was afkomstig van 'n Duitse skip die Königsberg wat deur twee monitors, die Severn en Mersey in die Rufiji rivier gekelder is in Maart 1915. 
enigste ongeval was toe 'n splinter 'n muur deurboor en 'n kok buite die hospitaal gedood het. ${ }^{18}$

Teen die einde Junie, nadat die reënseisoen verby was, het die hoofmag van Von Lettow Vorbeck na Dodoma begin terugval. Die Duitsers het teruggeval om die Sentrale Spoorlyn teen die opmars van generaal Smuts se magte te verdedig.

Van Deventer het in Augustus opdrag van generaal J.C. Smuts ontvang om dadelik na Morogoro op te ruk. Van Deventer het hierop die vyandelike magte wat deur Von Lettow Vorbeck agtergelaat is buite Kondoa Irangi, aangeval en oorwin. Hierna het hy dadelik reëlings getref om op te mars na die Sentrale Spoorweë om dit te beset, asook om hulp te kan bied aan die Britse hoofmag by Msiha.

Pantsermotors en 'n deel van die Suid-Afrikaanse Motorfietskorps is beveel om na Dodoma agter die Duitse magte aan, op te ruk. ${ }^{19}$ Met hulle aankoms in Dodoma vind hulle dit verlate van Duitsers wat intussen verder beweeg het om die spoorlyn tussen Kidete en Kilosso te verdedig. By Kidete het die Suid-Afrikaanse Motorfietskorps vir die eerste keer, nadat hulle uit Kondoa Irangi vertrek het, weer met die Duitsers kontak gemaak. As deel van Van Deventer se verkenningslinie het die Motorfietskorps gereeld in lokvalle beland. Die gebied tussen Kidete en Kilosso het hom ook uitstekend daartoe geleen. Lokvalle sowel as die goeie verdediging van die spoorlyn deur die Duitsers het tot gevolg gehad dat nie net die Motorfietskorps maar ook die 2 Divisie byna daagliks in hewige gevegte betrokke was.

As gevolg van swak padtoestande en die snelheid waarmee opgeruk is was dit moeilik om die soldate van die nodige rantsoene te voorsien. Ondervoeding het die soldate vatbaar gemaak vir byna enige tropiese siekte. Hierdie toestande het bygedra dat die Suid-Afrikaanse soldate tot die uiterste beproef is. Van die 6698 troepe in die 2 Divisie was 1946 ongeskik vir aktiewe diens. Van die 268 motorfietsryers was ongeveer 48 ongeskik vir diens. ${ }^{20}$ Sukses is slegs behaal deur die goeie samewerking en hoë moraal wat onder lede van al die eenhede bestaan het. $^{21}$

As gevolg van bogenoemde omstandighede en die daelange gevegte was Van Deventer genoodsaak om by Kilosso halt te roep. Daarop het die SuidAfrikaanse Motorfietskorps bo-op 'n koppie wat op die Bomarivier uitgekyk het, kamp opgeslaan. ${ }^{22}$ In Kilosso het die lede van die Motorfietskorps gaande geraak oor die heerlike kerrie en rys wat deur 'n Griek aan hulle verkoop is. Verskeie soorte sitrusvrugte was verkrygbaar, terwyl die maak van vetkoeke uitgeloop het op ' $n$ hele paar aanvalle van slegte spysvertering

Van laat slaap was daar ook geen sprake nie. Elke oggend om vyf-uur is die hele kamp gewek deur die Moslem-priester wat vanaf 'n balkon die soldate en inwoners saamgeroep het vir gebed.

Tydens hulle verblyf het die Motorfietskorps en die Britse Koninklike Vloot Lugmag toerusting begin uitruil. Vier BSA motorfietse is deur die Motorfietskorps verruil vir twee Lewis masjiengewere. Veral vanweë hulle laaste ondervindings het die Motorfietskorps gevoel dat groter en doeltreffender masjiengewere vir hulle van groot nut sal wees. ${ }^{23}$

\section{Aansluiting by Northey}

As gevolg van die verswakte toestand waarin 2 Divisie na die opmars na Kilosso verkeer het, sowel as die terugkeer van 12000 Suid-Afrikaners na die Unie na afloop van die verrigtinge in die Uluruge berge, was generaal Smuts verplig om die SuidAfrikaanse magte in Oos-Afrika te herorganiseer. ${ }^{24}$ Kort na die reorganisasie het Smuts die Oos-Afrika gevegsterrein verlaat om na Engeland, waar hy as lid van die Imperiale Oorlogskabinet sou optree, te vertrek.

Die gebeure het die Suid-Afrikaanse Motorfiets korps indirek geraak. Na Smuts se vertrek is generaal Van Deventer aangestel as opperbevelhebber van die Suid-Afrikaanse magte in OosAfrika. Die Motorfietskorps sou om die rede en om generaal Northey van hulp te wees, by hom aansluit.

Nadat Van Deventer se patrollies op 19 September met generaal Northey se krygsmag in aanraking gekom het, is beide die 8 Suid-Afrikaanse Infanteriebataljon en die Motorfietskorps onder bevel van luitenant-kolonel Taylor, aangesê om by Kilimatinde saam te trek. ${ }^{25}$

18. Official History, op. cit., p 73.

19. Hordern, C., luitenant-kolonel. History of the Great War Military operations, East Africa, volume 1, (London, 1941) p 329

20. Hordern, C., op. cit., p 327

21. Official History, op. cit., p 79

22. WWI, GSWA, Houer 102: Brief van Fairweather aan ADMS te Kilosso op 16 Oktober 1916

23. WWI, GSWA. Hover 106: Brief van luitenant-kolonel G.T.A. Beard, 2 Divisie, te Kilosso gedateer 6 Oktober 1916

24. Collyer, J.J., op. cit., p 239

25. Collyer, J.J., op. cit., p 239

Official History, op. cit., p 83. Die bron dui aan dat die 8 Infanteriebataljon en die Motorfietskorps onder bevel van Fairweather geval het. 
Die Motorfietskorps het dadelik vanaf Kilossa oor die Ruaha rivier na Dodoma vertrek om by Northey aan te sluit. Kort hierna is verskeie peletons uitgestuur na Ulete, Rungemba en Wassa. Hulle taak was om die kommunikasielyne vanaf Iringa en Malangali oop te hou.$^{26}$ Aktiewe patrollies is ook na die suide van Rungemba uitgestuur. Benewens die Korps se taak om patrolliewerk te verrig word hulle nou ook aangewend as berede infanterie. ${ }^{27}$

Die hoofrede vir hierdie stap lê in die feit dat petrolvoorrade al hoe skaarser begin word het. ${ }^{28}$ Gedurende die vier maande van diens by die Iringa front, was die Korps verplig om hulle motorfietse te stoor. Hulle word hierna aangewend as gewone infanterie, sonder die gewone en noodsaaklike nieblanke ondersteuning, klere of organisasie.

In die tydperk wat die Motorfietskorps onder Northey gedien het, was die peletons in die Iringa distrik gereeld in kontak met die Duitsers in Lukegeta. Gedurende dieselfde tydperk het motorfietsryers by Boma Himbo diens gedoen en op 23 November is 72 versterkings van die Korps na ' $n$ koorsdistrik in Dar-es-Salaam om daar diens te doen. ${ }^{29}$

\section{Geveg by Tandala}

Op 25 Oktober het 'n deel van die Duitse magte tussen Alt-Iringa en Ngominji deurgebreek. As gevolg hiervan het ' $n$ verskeidenheid klein gevegte gedurende die einde Oktober en begin November in die gebied uitgebreek. Tydens die skermutselings is ' $n$ hele aantal senior Imperiale- en Suid-Afrikaanse senior offisiere gedood.

Ongeveer 17 motorfietsryers onder aanvoering van luitenant-kolonel Fairweather was in 'n geveg naby Tandala teen die Duitsers betrokke. Hulle doel was om by kaptein Anderson, wat 25 kilometer van hulle af gestasioneer was, aan te sluit. Nadat hulle ' $n$ dag ver gestap het, het hulle teen die aand bo-op ' $n$ rif kamp opgeslaan. Aangesien die gebied vol Duitse magte was, is bevel gegee dat geen vure gemaak mag word nie.

Kort nadat die kamp opgeslaan is, is 'n Duitse Askari, wat onder bevel van kaptein Witgens was, gevange geneem. Van hom is verneem dat Witgens se mag sowat 300 tot 400 man sterk was. Verder was hulle bewapen met 21 masjiengewere en twee Krupp ses-ponders

Die volgende dag is die Duitsers gewaar, besig om reg op die kamp af te stap. Dit wil voorkom of die draers van die Motorfietskorps, nadat hulle die vorige nag weggedros het, die Duitsers in kennis gestel het van die kamp. Fairweather het dadelik aan 'n Lewis masjiengeweerseksie bevel gegee om dekkingsvuur te bied, terwyl hulle terugval.

Die Duitsers het dadelik begin terugskiet. Fairweather se mag moes inderhaas terugval. 'n Duitse Askari het egter ongesiens deur die lang gras beweeg en op die terugvalsroete stelling ingeneem. Met die haastige terugval het die motorfietsryers tromp-op in die Askari vasbeweeg en Fairweather is doodgeskiet. Die res van sy manne is almal gevange geneem, onder andere ook Wally Clarkson, 'n voormalige Springbok rugbysenter.

Teen die namiddag is luitenant-kolonel Fairweather deur die Duitsers begrawe, terwyl kaptein Witgens self die begrafnisrede gelei het.

Die res van die Korps wat in die nabyheid was, was nou verplig om tydelik in die omgewing van die Wiedhafen pad te kampeer. Hier het hulle gebly tot versterkings opgedaag het. Luitenant Jackson het later met versterkings opgedaag en bevel oorgeneem. Met die aankoms van ' $n$ kompanie van die King's African Rifles onder bevel van kaptein Masters, is besluit om Tandala te verdedig. ${ }^{30}$

Na ' $n$ hewige geveg van meer as twee uur het die Duitse magte padlangs na Tandala begin beweeg. Hierop het kaptein Masters bevel gegee dat die Motorfietskorps dadelik moes terugval, aangesien hulle alreeds meer as 60 persent ongevalle gely het.

Die motorfietskorps het in klein groepies verdeel. Sommige het na Njombe beweeg terwyl die ander na Tandala is. Vanaf 22 tot 28 Februarie 1917 is Tandala onder bevel van majoor Ballantine verdedig. Op die oggend van 28 Februarie word die Duitsers vanaf Tandala teruggedryf. Direk hierna is 'n 24-uur wapenstilstand gereël waarop die siekes en gewondes van beide kante na 'n hospitaal tussen die twee linies geneem is.

26. WWI, GSWA, Houer 108: Order aan Fairweather vana 2 Divisie Hoofkwartier gestasioneer op Kondoa Irangi gedateer 21 Desember 1916.

27. WWI, GSWA, Houer 106: Memorandum van luitenantkolonel Faitweather aan brigadier E. Northey te Malingali, gedateer 9 Februarie 1917.

28. Ibid

29. WWI, GSWA, Houer 106: Memorandum van Fairweather aan brigadier-generaal E. Northey te Malingali, gedateer 9 Februarie 1917

30. AG(3), Houer 204: Verslag saamgestel deur sersant J.R Williams in 1943 
Hierna vertrek die Suid-Afrikaanse Motorfietskorps vanaf Tandala na Iringa om hulle gestoorde motorfietse weer in gebruik te neem en na Lupembe sendingstasie te vertrek. Majoor McMillan, MC, wat op 6 Maart aangestel is as die bevelvoerder van die Motorfietskorps, het intussen twaalf Lewis artilleriste na Zomba gestuur. Hulle sou as instrukteurs in die 1 Kings African Rifles dien. teen die Duitse magte wat daarheen opgetrek het. Hier was húlle vir drie dae lank in hewige gevegte met die Duitsers betrokke. Hoewel Von Lettow Vorbeck, die aanvoerder van die Duitse magte in Oos-Afrika, 'n uitstaande bevelvoerder en strateeg was, moes hy egter op 28 Augustus terugval. Slegs 'n aantal skerpskutters het agtergebly om sy agterhoede te dek.

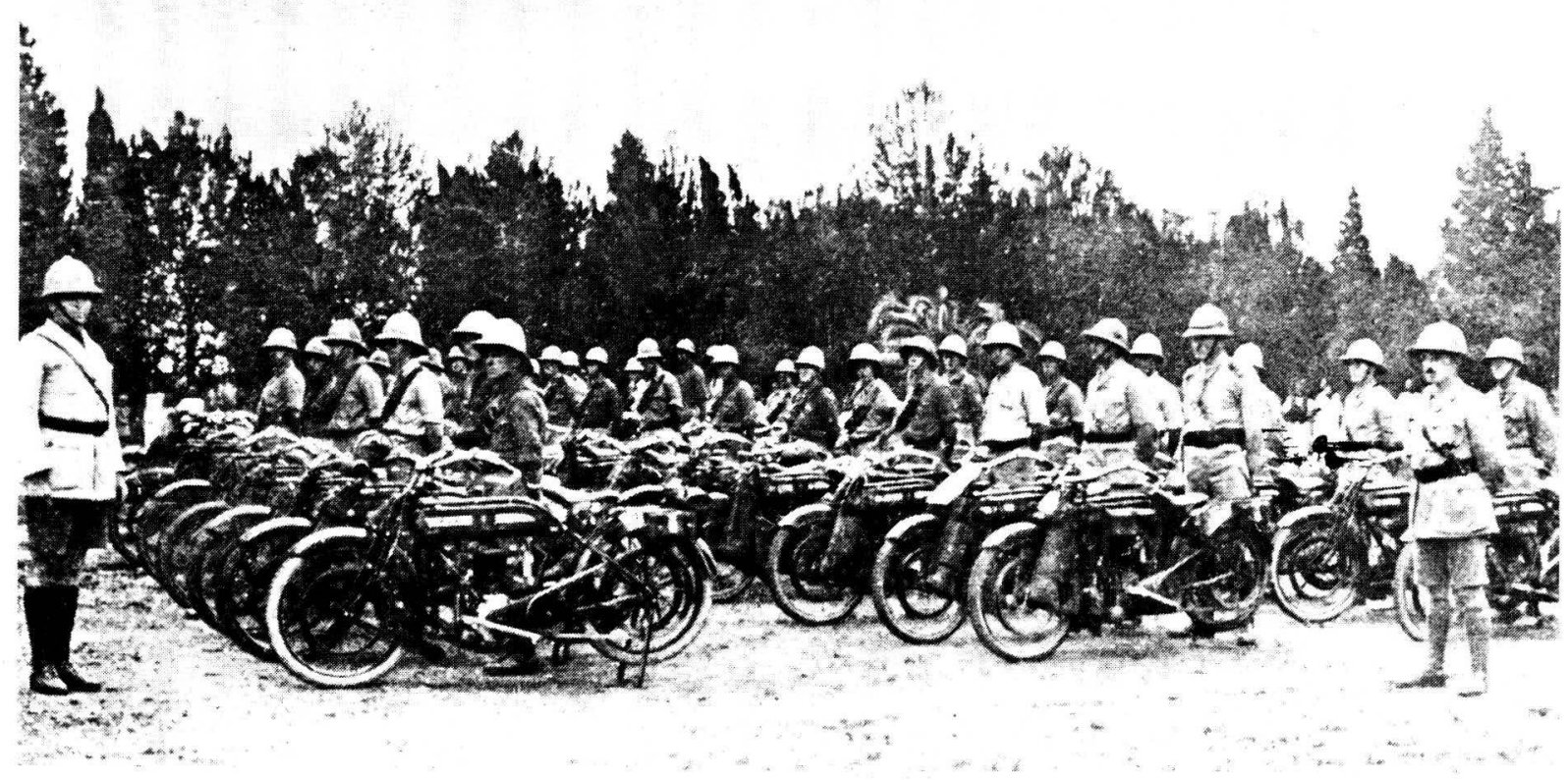

Lede van die Suid-Afrikaanse Motorfietskorps te Zomba, Nyasaland. (Foto: SAW-Argief.)

Tydens die Suid-Afrikaanse Motorfietskorps se verblyf in Lupembe het hulle saam met lede van die Nyasa-Rhodesiese Veldmag ' $n$ aantal patrollies onderneem. Vanaf Lupembe het die Korps oor sanderige paaie na Mpurakasessi en van daar na Songea beweeg

By Kigonserra sendingstasie het hulle ' $n$ hele paar dae oorgebly alvorens die laaste skof oor die Livingstone berge aangepak is na Mbamba Baai. Om oor die berge te trek moes verskeie kere van toue gebruik gemaak word om die motorfietse oor die kranse te hys.

Teen Kersdag is die Suid-Afrikaanse Motorfietskorps met die stoomboot, Chauncey Maples na Fort Johnston, Zomba en daarvandaan na Blantyre. Die groot rede vir die geweldige opmars was om Von Lettow Vorbeck se mag in Nyasaland en Mosambiek te stuit.

Teen April 1918 is die Motorfietskorps na Regona in Mosambiek om die Rovuma rivier te verdedig
Vanaf Regona is die Motorfietskorps na Malagatera, Lake Amaramba en Ndoka. Van hier af is luitenant Webb saam met kolonel Baxton na die Lugenda rivier. Die agtervolging van die Duitsers was egter tevergeefs. By die Revuma rivier is hulle deur inboorlinge meegedeel dat die Duitsers alreeds die rivier oorgesteek het. Teen die einde van September keer die Korps onverrigter sake terug na Namweras.

\section{Die einde van die oorlog}

Luitenant Campbell en ' $n$ deel van die Motorfietskorps het vanaf Namweras oor die Nyasa rivier na Mwaya en vandaar na die Igala pas beweeg. Die Motorfietsryers is in hierdie gebied gestasioneer en het opgetree as rapportryers na Fife.

Op 12 November is twee motorfietsryers vanaf Fife na Von Lettow Vorbeck, naby die Kasama sendingstasie, gestuur om aan hom die boodskap te bring dat op ' $n$ wapenstilstand ooreengekom is. Hoewel hulle onder die duidelike vertoon van ' $n$ wit vlag nader gery het, is hulle dadelik gevange geneem. 
Luitenant Webb het intussen met nog 'n aantal motorfietsryers by luitenant Campbell aangesluit. Saam beweeg hulle in die rigting van Kasama. By Line Head kon hulle 'n telefoonberig na kolonel Hawkins van die Kings African Rifles deurstuur. Op sy beurt het Hawkins aan Von Lettow Vorbeck die volle besonderhede rakende die wapenstilstand gestuur. Hierop het die Duitse magte na Abercorn terugbeweeg.

'n Seksie van die Motorfietskorps wat in Noordoos Rhodesië diens verrig het, het aangesluit by die Korps in Zomba. In opdrag met die Demobilisasie Order wat uitgereik is deur brigadier-generaal Hawthorn, DSO op 20 November te Zomba, ${ }^{31}$ het die SA Motorfietskorps na die Unie teruggekeer via Chindi, Beira en Suid-Rhodesië.

\section{Slotsom}

Generaal Northey was by uitstek die man wat die waarde van die mobiliteit van die Motorfietskorps besef het. Die snelheid waarmee die Korps ' $n$ gevaarsone kon bereik het hom goed te pas gekom. Verder het Northey dikwels motorfietsryers vanaf Zomba na Dar-es-Salaam gestuur met dringende boodskappe. Dit was omrede daar nie altyd rapportryers beskikbaar was nie.

Gedurende die twee jaar van aktiewe diens het sowat 1000 persone by die Motorfietskorps aangesluit. Van die oorspronklike lede wat met die Korps se stigting gewerf is, het teen Januarie 1918 slegs vyftien oorgebly. Ongeveer 34 offisiere en ander range het in Oos-Afrika gesneuwel, terwyl die res óf gevange geneem is, óf ongeskik was vir aktiewe diens weens siektes of skietwonde. ${ }^{32}$

Hoewel die SA Motorfietskorps hom uitstekend van sy taak gekwyt het en aan gevegte by Kondoa Irangi, Kidete, Iranga distrik, Tandala en Regone deelgeneem het, is geen ere-kleure of gevegsonderskeidings aan die eenheid toegeken nie.

Met die aankoms van die Korps op Robertshoogte is die SA Motorfietskorps onmiddellik ontbind.

31. WWI, GSWA, Houer 102: Brief van luitenant W.J. Houghton aan DAAG te Zombo op 4 Desember 1918.

32. AG(3), Houer 204: Verslag opgestel deur sersant J.R. Williams in 1943. 